\title{
鷄精液の生化学的研究 II
}

各種呼吸阻害剂が鵎精子の代謝並に運動性に及ぼす影響について

\author{
吉田 重 雄・析 田 博司 \\ （京都大学農学部畜産学第二講座）
}

(1965. 2. 19 受付)

著者らほ前報200において，鵎精子においても哺乳類精 子の場会と同様に，呼吸之解糖上が精子の運動を維持す

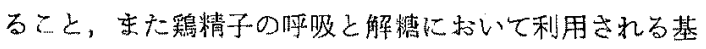
質の種頪について報告した。

その結果，鷄精子に扗いては哺乳類家畜精子の場合と 異なり，精子の運動性の維持に関しては，呼吸の方が解 糖よりも相対的に重要な意義を有するように思われたの で, 本報においてはさらにこの点艺確かめるために，数 種の呼吸阻害剂を添加した際の, 鶂精子の呼吸, 解糖に 及ぼす変化ななら゙に鷄精子の運動性に及ぼす影響につ いての検討を行つた。

\section{実験材料ならびに方法}

1）精子浮游液の調製：実験に用いた材料および精子

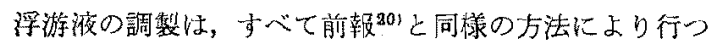
たもので，目的に応しててれぞれ Ca 欠 KRP または KRBによる1回洗使精子浮游液（6８倍）をつくつた.

2）呼吸ならびに好父的解糖の測定：前郝と同じく WARBURG 検任法により呼吸を，杰た化学的定量法によ り好気的解螗を測定した。

反応液の組成はつぎの通りである。

主室 $\mathrm{Ca}$ 欠 $\mathrm{KRP}$ に上る 1 回洗湤精子浮游液 $2.0 \mathrm{~m} l$ $\mathrm{Ca}$ 欠 KRP またはブドウ糖㖡（終末漄度

$$
0.02 \mathrm{M} \text { ) }
$$

$0.5 \mathrm{~m} l$

㑡室 各種阻害㓱の $\mathrm{Ca}$ 久 $\mathrm{KRP}$ 溶液

$0.3 \mathrm{~m} l$

$\mathrm{Ca}$ 久 $\mathrm{KRP}$

$0.2 \mathrm{~m} l$

副室 $20 \% \mathrm{KOH}$

$0.3 \mathrm{~m} l$

(但し $\mathrm{KCN}$ 添加の場合のみ $\mathrm{KCN}-\mathrm{KOH}$ 混合液 $0.3 \mathrm{~m} l)$

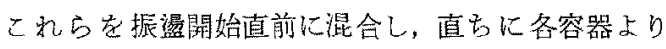
$0.5 \mathrm{~m} l$ 宛のサンプル採取を行い， $40^{\circ} \mathrm{C}$ で前振り 15 分, 以兴 120 分間の振㬁を行つて酸菜消費量の測定老行つた 直㣪，再び $0.5 \mathrm{~m} l$ 宛のサンプル定採取した。な打ブド ウ糖の消失量は ANTHRONE 法16) を用いて定量を行つた
が，やはり前報同様，しばしば原因不明の還元值が出現 したため参考とするに留め, 主として BARKER and SUMMERSON 法 ${ }^{1}$ による生成乳酸量によつて解糖量の判定 を行つた.

また $\mathrm{pH} の$ 影響を防ぐために，用いた阻害制はすべて $\mathrm{pH}$ 安 7.2〜7.4 に調整した.

3) 匑気的解糖の测定：WARBURG 検生法と化学的定 量法とを併用した，その理由は，WARBURG 検生法は阻害 の時間的な変化， lag phaseなどを筧察することができ， 便利であるが， $\mathrm{CO}_{2}$ の発生は必ずしも生成乳酸量に特暴 的ではない欠点を有し，また BARKER and SUMMERSON 法は乳酸生成量を正確に測定することができるが，ある

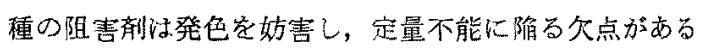
ので，両者を併用するこにによつてそれぞれの久点を補 うことに妢めた訳である。

玉下反応液の組成柱，Ca 久 KRB 飞上る精子浮游液 を用いたほ方は前項の通りである。な和反応液の混合 およびサンプルの採取む前項同㥞に行つた後, 值古に $95 \% \mathrm{~N}_{2}, 5 \% \mathrm{CO}_{2}$ でがス交換を行つた.

4）運動の観察：WARBURG 検圧法沉よる測定の前後 には顥微鏡下で精子の活力, 生存宰観察するととも に，沪紙法により $\mathrm{pH} の$ 変化を測定した。な打嫌気的条 件下の阻害実験の際には, 容器をマノターターがらはず

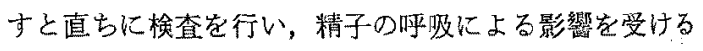
のを防くことに努めたまたたずれの阻害判について む, 実験終了後直ちに精子を $\mathrm{Ca}$ 欠 $\mathrm{KRP}$ または KRB

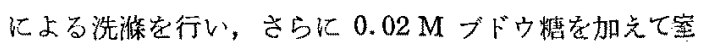
温に 1〜2 時間放置し，運動性の回復につき検討老行つ

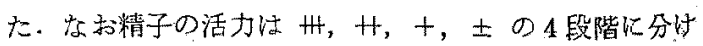
て，これに 100，75，50，25 の值老与え，之れに各段 階に属する精子の\%を掛けたものの和を100で割り， この数值を生存指数として表わした.

5）結果の整理：各阻害郕について阻害浱度を決定湘 る当り，同一実験を数回反覆して行つたが，すべて 
濃度に亘つて毎回行うことは，検圧計のマノメータ一本 数の制限があり，不可能であつた。一方鵎精液の性状は 每回ある程度の変動省し，それに伴つて呼吸量 $\left(\mathrm{ZO}_{2}\right)$, 解螗量 $\left(\mathrm{Z}_{\mathrm{L}}^{\mathrm{O}_{2}}, \mathrm{Z}_{\mathrm{L}}^{\mathrm{N}_{2}}, \mathrm{Z}_{\mathrm{CO}} \mathrm{N}_{2}\right)$, 活力などの值もそのつど变 動を示した. 侻らて Ca 欠 KRP による1回洗滌精子浮 游液を毎回詨照にとり，乙れと各浱度の阻害郕添加時の 測定值との間に阻害度を求め, 各溦度ごと红每回の阻害 度の平均值を100より引いた值を対照の平均值に掛けて， それぞれの濃度における補正值を算出した。すなわら $C_{1}, C_{2}, C_{3} \cdots C_{l}$ を毎回の刘照の測定値とし， $X_{1}, X_{2}, X_{s} \cdots X_{m}$ をある種の阻害削のある浱度の測定值, $Y_{1}, Y_{2}, Y_{8} \cdots Y_{B}$ を同じ阻害剂の別の浱度の测定值とす ればそれぞれの補正值 $X, Y$ は次式のごとくになる。

$$
\begin{aligned}
& X=\frac{\sum_{i=1}^{l} C_{i}}{l} \times\left\{100-\frac{\sum_{j=1}^{m} \frac{C_{j}-X_{i}}{C_{j}} \times 100}{m}\right\} \\
& Y=\frac{\sum_{i=1}^{l} C_{i}}{l} \times\left\{100-\frac{\sum_{k=1}^{n} \frac{C_{k}-Y_{k}}{C_{k}} \times 100}{n}\right\}
\end{aligned}
$$

但し, $l, m, n$ 沫 それぞれ，対照， ある阻害削のある嶩度\}の実施回数を示す。 同じ阻害凨の別の裖度

\section{実 験 成 績}

\section{1) マロン酸 $\left(\mathrm{CH}_{2}(\mathrm{COOH})\right)$}

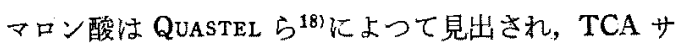
イクル中のコハク酸脱水素醉素に対し，コハク酸と競合 的 (competitive) に阻害することで有名な阻害绪である が，これを Ca 欠 KRP による精子浮游液，およびこれ

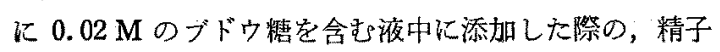
の呼吸, 解糖䄧よび運動性に対する影響を一括して図示 すれば，第 1 図のごとくである.試みた $0 \sim 10^{-2} \mathrm{M} の$ 濃度のうち, 低濃度では, 基質無添加区, ブドウ悺添加 区共に阻害江認多られないが, $10^{-2} \mathrm{M}$ の濃度では, 基質 無添加区で活力のみにやや低下が起つた. 一方ブドウ糖 添加区では, 呼吸が約 10\%の阻害定受け，その影響によ り乳酸生成量活逆に促進を示したが, 活力は $10 \%$ 程度 の阻害を受けた。

第 2 図は阻害剂とともにコ八ク酸を添加した場合の阻 害の結果を示している。 コ八ク酸添加により Ca א KRP 区，ブドウ糖添加区を問わず精子の酸素消費量が著しく 增すが，Ca 欠 KRP 区で注，10-4 M からすでに約 $10 \%$

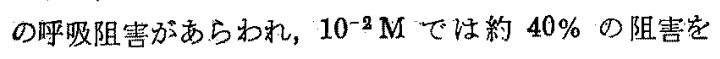

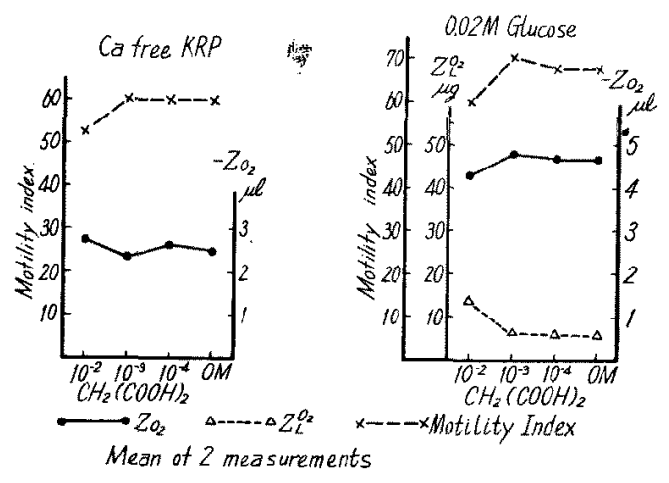

Fig. 1. Effect of malonate on the respiratory metabolism of fowl sperm.

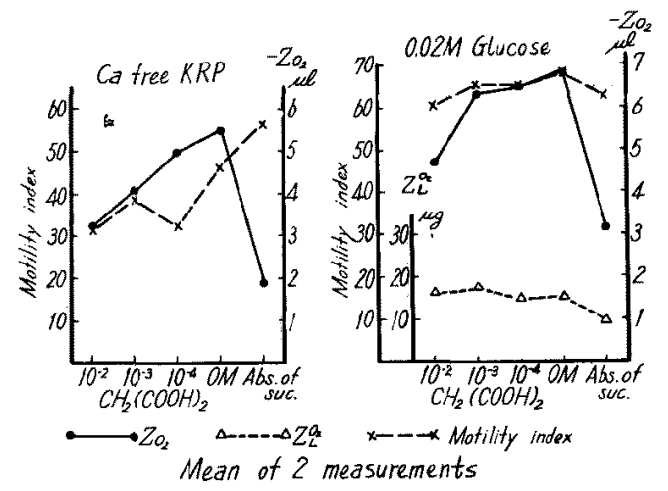

Fig. 2. Effect of malonate on the respiratory metabolism of fowl spem. (In the presence of succinate)

示し，宗た活力も $10^{-4} \mathrm{M}$ ですでに約 $30 \%$ の阻害を受 けた：このことは，コハク酸添加炕基づく酸素消費量の 増加がーロン酸によつて抑制を受け，再び内因性呼吸レ ベルに戻ることをよく示している。一方ブドウ糖添加区 では, 第 1 図の場合と同様に, $10^{-3} \mathrm{M}$ むでは阻害はき わめて僅かで，10-2 M においてのみ約 $30 \%$ の呼吸阻 害を示したが, 活力は約 $10 \%$ の阻害に留まった. 以上 の結果必ら，鵎精子の哂吸代対主るマロン酸の阻害は， 内因性呼吸汇はすり作用しないが，ブドウ糖を基質に すれ法若干あらわれ，またュハ夕酸を基澌にした時に最 あ大きくあらわれることが明らがされた。なお、ロン 酸の添加に上り，ブドウ糖添加区の乳酸蓄積量がやや増 すのが認められたが，これが解糖の促進であるかどうか を確かめるために，娧気的条件下でマロン酸を添加し， 解糖への影響をみたのが第3图である。すないらマッン

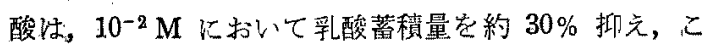


吉明・枰田

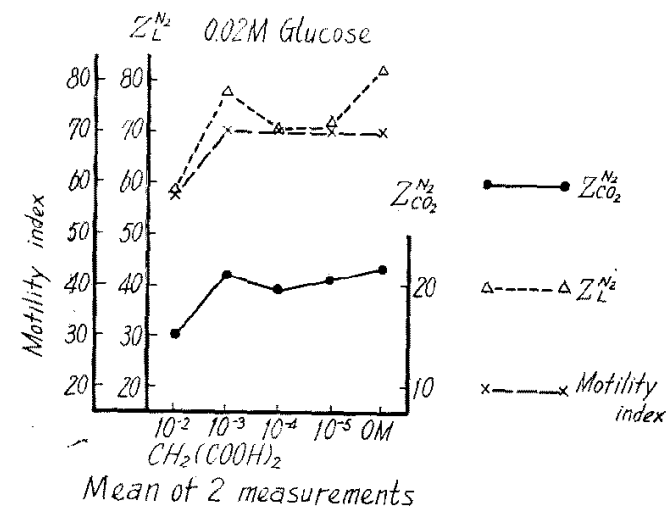

Fig. 3. Effect of malonate on the anerobic metabolism of fowl sperm.

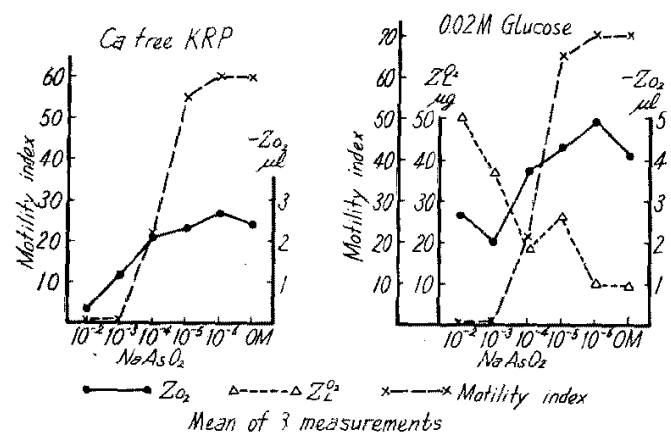

Fig. 4. Effect of arsenite on the respiratory metabolism of fowl sperm.

れに併行的に活力むまた阻害されているのがわかる。従 つてこのことから，好気的条件下に怙けるマロン酸添加 区に認められた蓄積乳酸量の増加は，TCA サイクルの 阻害の結果，2 次的汇起るるが上の解煻促進であると 思われる。

2) 7 上酸 ( $\left.\mathrm{H}_{3} \mathrm{AsO}_{\mathrm{s}}\right)$

フヒ酸はSH 阻害棛であり, TCA サイクルの $\alpha$ ケト グルタル酸脱水素酵素を不可逆的任阻害することが知

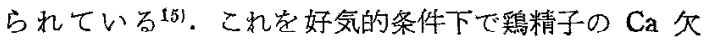
KRP 浮游液およびブドウ糖加浮游液代添加した際の呼

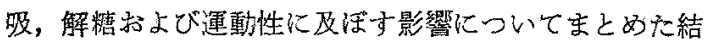
果を第 4 図に示寺。

図のごとく，無基質区，ブドウ梼添加区ともに $10^{-6} \mathrm{M}$ では 10 20\% 程度の呼吸促進が認められるが, さらに

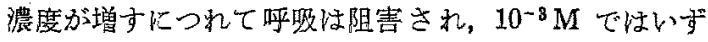
れる約 $50 \%$ 阻害となり，無基質区では $10^{-2} \mathrm{M}$ でほ

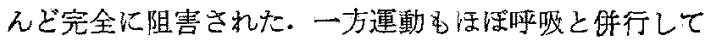

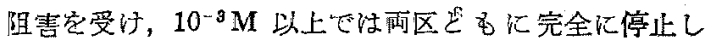

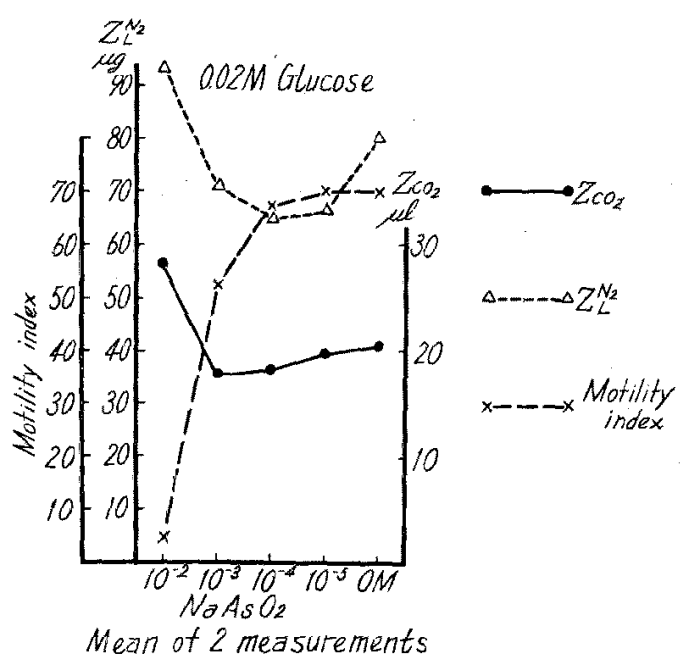

Fig. 5. Effect of arsenite on the anerobic metabolism of fowl sperm.

ていた。これに反し，蓄積乳酸量につ七酸漲度の增加と そむに著しく堌し， $10^{-\mathrm{z}} \mathrm{M}$ では $50 \mu \mathrm{g}$ にも達した。 こ の場合は単なるみかけ上の解糖促進で注ないととが，同 時汇行つたブドウ栯の消失量 $\mathrm{Z}_{\mathrm{G}}^{\mathrm{O}_{2}}$ が，ほぼ $70 \mu \mathrm{g}$ 示 したことから確かめられた。 この関係をさらに明らが するために，骤気的条件下に打いて同様の実䮖行つた が，その結果を示せば第 5 図のごとくである。この場合 も促進の度注異なるが，10-2 $\mathrm{M}$ に和いては解糖が明ら かに促進されていることが認められた，一力，それにも 拘らず精子の活力は， $10^{-3} \mathrm{M}$ 汃ら著しく阻害された。 このことはア上酸が熑気的状態においても精子の運動に 対する阻害, しか子明らかに解糖とは別の系に対し阻害 することを示しており，注目される．ただこの際の阻害 は，好気的条件下に打ける阻害と比べると，幾分程度が

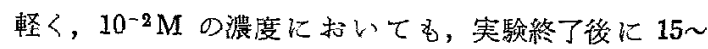
$20 \%$ の精子が土程度の運動を示していた．な和実験終 了後にブドウ糖加 $\mathrm{Ca}$ 欠 KRPで精子を洗い，賦活試験 を行つたか；1時間を経ても精子の活力は回復しなかつ た.

3) フルオロ酰酸 $\left(\mathrm{CH}_{2} \mathrm{FCOOH}\right)$

フルオロ酢酸は単離された個々の酵素に海用せず, 生体内で才キサ口酷酸と結合してフルオロクエン酸とな り，はじぬて Aconitase に対してクエン酸と競合的に 阻害するととが知られている11)。

まず好気的条件下で 2 例について行つた結果を第6図 に示す。この際はフルオ口酶酸を側室に入れたが，無基 質区で注呼吸は $10^{-8} \mathrm{M}$ より，活力は $10^{-4} \mathrm{M} よ り$ 阻害 


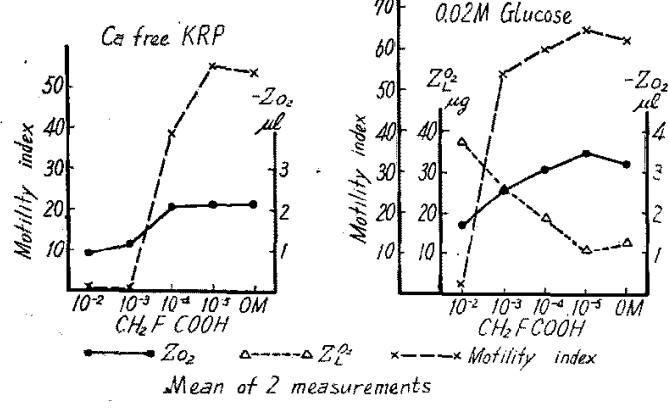

Fig. 6. Effect of fluoloacetate on the respiratory metabolism of fowl sperm.

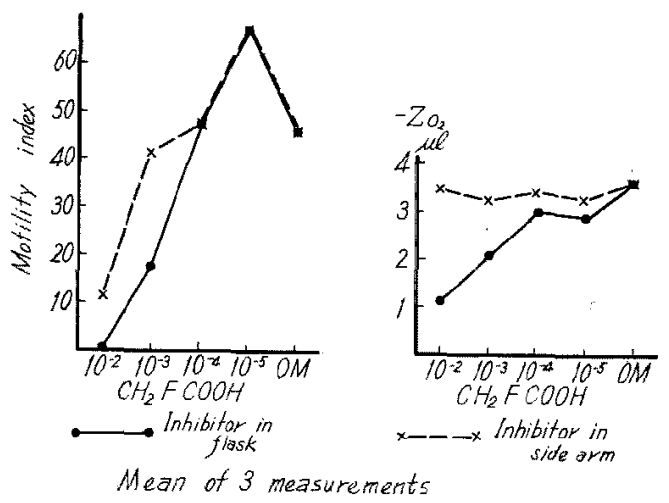

Fig. 7. Effect of fluoloacetate on the respiratory metabolism of fowl sperm (in the presence of sodium acetate).

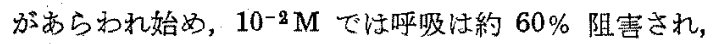
活力注注とんど停止していた。一方ブドウ糖添加区に

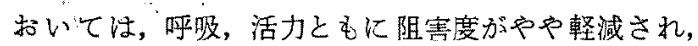

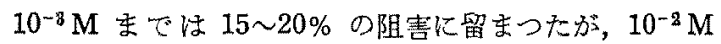
では呼吸が的 $45 \%$ の阻害受け，活力にも強い阻害が あらすれた。主解糖は, 消失糖量, 生成乳酸量ともに 呼吸の阻害度に応し，代償的に促進されているのが認め られた。

次に，フルオロ酷酸の阻害の性格安明らかにするとと を炕，酶酸が果して鷄精子によつて利用されるかどうか を確かめる目的で，はじめからフルオ口酶酸主室に入 れ，酶酸ソーダを側室に入れた場合上，逆に眽酸ソーダ を主室に，フルオ口酢酸を側室に入れて後から混合した 場合とて，Ca 欠 KRP 浮游精子に対する阻害度がどの ように異なつてくるか它確かめてみた。なおこの際はで きるだけ両区の差異をはつきりさせるために，側室から の夜の混合は前振り 15 分の後に行つた. その結果は第 7 図のごとくであり，フルオ口酶酸主室に入れた区で は醀酸ソーダの影響を受けず, $10^{-8} \mathrm{M}$ 上り強い呼吸阻
害を示し，活力もまた強く阻害された。一方酶酸ンーダ を主室,フルオ口酶酸を㑡空の区ては，むしろ前者の影響 が強くあらわれ，呼吸にはほとんど阻害はあらわれず， また活力の阻害む就減されて，西区の差は明らかであり た。なおクェン酸，および前報で舄精子に対して呼吸促 進の度の強かつたコハク酸を加えて, 同樣な実験を行つ た結果定てれぞれ第 8 図，第 9 圆に示す。クエン酸添加 の際は酶酸ソーダ添加の場合よりも雨区の差は少いが， 呼吸に対しては，阻害剂をはじめから主室に入れた方が やはり阻赛が強くあらかれており，活力にお゙いてはほと んど差が認められなかった。一方コハク酸の場合には, 両区の間にあまり明らかな差沬認められなかつた。

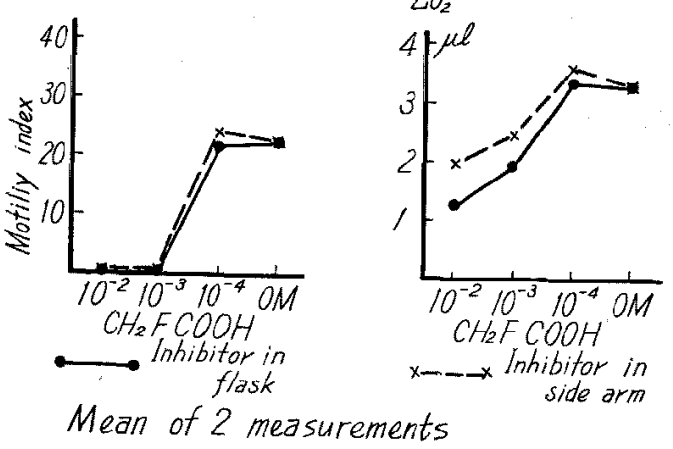

Fig. 8. Effect of fluoloacetate on the respiratory metabolism of fowl sperm. (In the presence of citrate)
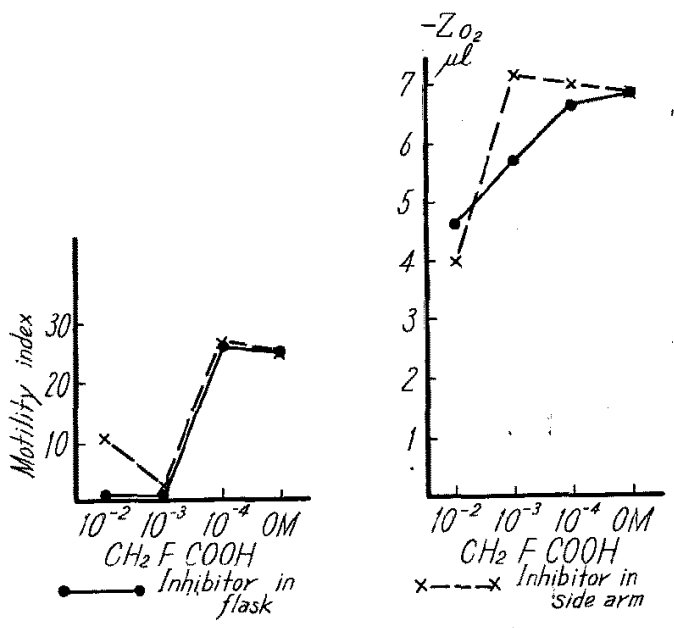

Mean of 2 measurements

Fig. 9. Effect of fluoloacetate on the respiratory metabolism of fowl sperm. (In the presence of succinate) 
吉田・析田

\section{4）シアン化カリ（KCN）}

KCN はチトクロームオキシダーゼをはじめ,種々の 酸化䤃集の活性中心である金属と結合してこれを不活性

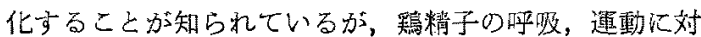
する影響につき検討を行つた結果第10图に示す。な おこの際， $\mathrm{KCN}$ は副室内の $\mathrm{KOH}$ に吸収されること标 知られているので，用いる濃度に応じ副室内の $\mathrm{KOH}$ に

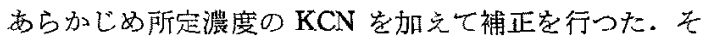
の結果，無基質区，ブドウ糖添加区のいずれの場合にす 呼吸を強く阻害し， $10^{-8} \mathrm{M}$ て $80 \%$ 以上の阻害を示し た. 運動の阻害も呼吸の阻害と併行してあらるれ，奥基 質区では $10^{-4} \mathrm{M}$ 以上の朢度でほとんど停止していた。 一方ブドウ糖添加区に掠いては，呼吸の阻害度に応じて 代償的に解糖量が著しく促進されるのが認められたが， 活力に対寸る阻害度は無基質区の場合上りも僅か江軽減 されたにすぎなかった，さらに嫌気的条件下において KCN 汃解糖および運動に及ぼす影響につき検討安行つ た結果は，第11図のごとくである。この場合は KCN

Ca free KRP

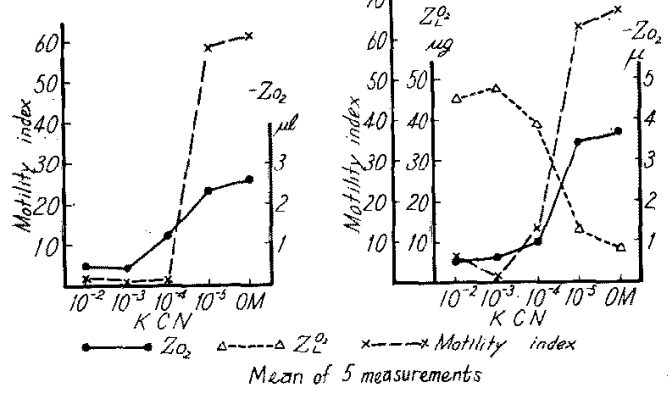

Fig. 10. Effect of pottasium cianide on the respiratory metabolism of fowl sperm.

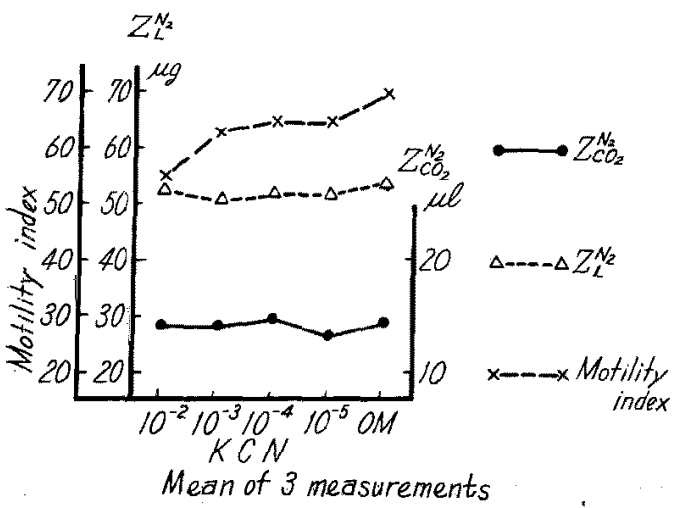

Fig. 11. Effect of pottasium cianide on the anerobic metabolism of fowl sperm.
濃度が增しても；解糖にはほとれど変化が認められず，

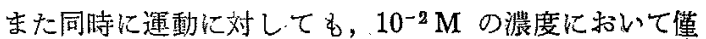
かに $20 \%$ 程度の阻害に留まり，精子は 120 分の代謝後 においても活発な運動を続けていた。

5) ヒドロオキシルアミン $\left(\mathrm{NH}_{2} \mathrm{OH}\right)$

ヒドロオキシルアミンは醉素の活性中心である $\mathrm{Fe}$ や 酥素をた璂筫の-CO-基と結合することによって阻害 を起すことが知られ，TCA サイクルでは $\alpha$ ケトグルタ 儿酸脱水素酵素, サタシニル CoA 燐酸転移酵素, 縮合 酵素系を阻害することが知られている ${ }^{17}$ ，第 12 因は七 ドロオキシルアミンが䳕精子の呼吸, 解糖叔よび運動性 に対する影響について調べた結果を示しており，無基筫 区，プドウ糖添加区を通じ，呼吸は $10^{-4} \mathrm{M}$ までは大し て抑制されないが， $10^{-8} \mathrm{M}$ 以上で恃著しい阻害を示し， $10^{-2} \mathrm{M}$ では約 $55 \%$ の阻害を示した。この際の活力の阻 害む呼吸の阻害とよく一致していた，一方ブドウ糖添加 区における生成乳酸量は，呼吸の阻害度が増すにつれて 著しく堌加する傾向空認ぬたにもかかからず，精子の活 力はそれによつて阻害が軽減される傾向は少しも認めら れなかった。

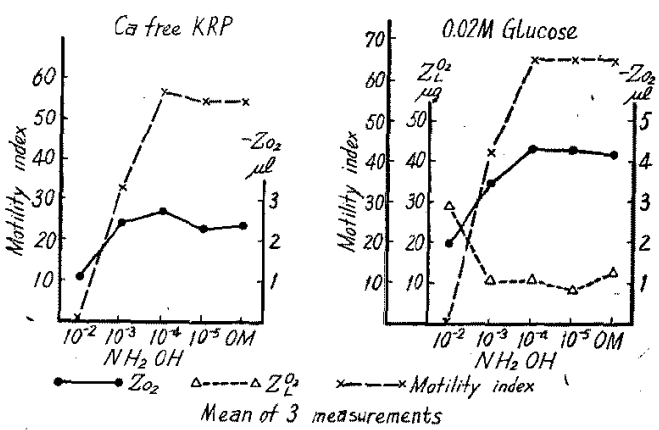

Fig. 12. Effect of bydroxylamine on the respiratory metabolism of fowl sperm.

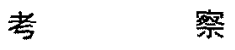

従来，哺乳頪家畜精子に対寸る各種阻害剂添加の影響 Kついて恃, 牛で LARDY and PhLlLips ${ }^{8 \sim 10)}$, Tosic and WALTON $^{19)}$, Howe and FLIPSE ${ }^{2)}$, 羊で MANN and LuTWAK-MANN ${ }^{(4)}$ ，豚で石渡 ${ }^{3 \sim 7}$ ほか子な゙の研究があり， また人で浪 MACLEOD ${ }^{121}$ ，MACLEOD et at. ${ }^{181}$ の報告肪要 るが，とくに LARDY et al. と石渡ほかの報告が詳しく 系統的に行わ礼ている。著者らは䳢精子の Ca 欠 KRP による1回洗源精子に対し，呼吸系阻害削 5 種をそれぞ れ単独に添加，あるいはブドウ楉その他の基質ととも沉 
添加することにより，鶂精子の呼吸，解糖，および连動 性に坟する影響について梌討を行つたが，その結果は， 鵎精子の代謝においても牛，羊，豚の精子と同じく， TCA サイクル，解糖における EMBDEN-MEYERHOF の径 路が存在すると若えてはじめて理解されることが多い。 以下個々の具体例定あげて，哺乳類精子との比較安行い つつ考察する。

1. 鵎精子の呼吸における TCA サイクルの存在につ

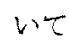

著者ら注前報登において, TCA サイクルのメンバー が鷄精子の㭔吸を促進することを報告したが，本報的 いてむTCA サイクルの阻害剂として知られているるの の添加により，鷄精子の呼吸が阻害をうけ，同時に運動 性も阻害されることが観察された。

すなわち，鵴精子にフヒ酸を添加すれば，無基質区， ブドウ糖添加区を問わず呼吸佁い阻害をうけ，活力屯 またこれに併行して阻害をうけた。 またフルオ口酶酸 は，生体内でフルオロクエン酸に合成されてからはじめ て阻害作用を示すことが知られているが，その添加は無 基質区，ブドウ糖添加区ともに呼吸，活力を併行的に阻 害したこと，またとくに酶酸ソーダとフルオ口酶酸とを 交互に主室，側空に入れて行つた害験沈いて，阻害削 定室に入れた場合のみに強い呼吸阻害が認められ，ま た活力阻害むはつきりとその差を示したこと，さらにク エン酸ンーダで同様の実験を行つた際にも，程度の差は あるが同様の傾向を示したことは，酶酸が活性化されて TCA サイクルに入り，才キサロ酶酸乙縮合し，クェン 酸となつて呼吸に利用されていることを証明すると同時 に，フルオロ酢酸る同様に TCA サイクルス入リ，クエ ン酸と競合的に Aconitase 阻害していることの最も よい証明になるものと考光る。立たヒドロオキシルフミ

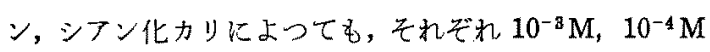
から著しい阻害をうけ，活力もこれにほほ竍行して阻害 を受けるのが認められた。

以上はすべて鷄精子の呼吸が運動と密接な関係を持つ ており，TCA サイリルを通るととを思わせる。ただマ ロン酸のみ泛ンク酸を基質にした場合のほかは内因性 呼吸に対しては無影響で，ブドウ糖添加区に対しての影 響むきわめて弱かつた，しかしこのことは豚精子につい ても全く同様のことが認められており，石渡》はこれに かいて，1）マロン酸のごときdi-carbon 酸は精子細胞 内にとくに入り難いこと，2）従って内因性の基質やブ ドウ糖が基質の場合には，生じたコハク酸は精子の内部 にあり，そのため外から入るマロン酸に比べてコハク酸 脱水素醉素に接触しやすい条件下にあること，3）、ロ
ン酸によるコハク酸々化は，プドウ裾先の他を基質にし た場合に比べて，より直接的であることなどの原因をあ げている．これらの原因が著者らの鷄精子の場合にその 生当て嵌生るか否か以别にしても，以上あげた各種呼 吸阻害实駼，とくにフルオ口酢酸と酷酸ンーダとの競合 の成續は，TCA サイクル証明の有力な材料となりうる ものと考える. 以上を綜合すれば，鷭精子の呼吸が TCA

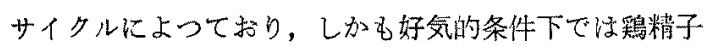
の運動に密接に関連し，有力な運動のエネルギー供給源 となつていると考劣ても差支えないと思われる。

2. 呼吸阻害剂が鵴精子の解䌅に及ぼす影響について 著者らは前報 ${ }^{20}$ 亿怙いて，Ca 欠 KRPに上る1回洗 滌精子に対し，各種の糖頑を添加して解䌅を睍定した結 果, ブドウ糖, 果糖, マンノ一スは好気的条件下, 㛎気 的条件下のいかえ定問わず乳酸生成为認められるが，好 気的条件下の解糖量は，螊気的条件下のそれと比べると 著しく小さいこと，また少なくとる㒇気的条件下では， 鵎精子の運動性は解糖によつて支持されること老明らか にした．今回，呼吸阻害敦として知られる5種の阻害刘 を好気的，あるい泟㜋気的条件下で添加寸ることによ り，解糖に対する影響につき調べた結果，興味ある知見 が得られた、すなるち、マロン酸を除き，試みた呼吸阻 害戍はいずれる呼吸老阻害すると共に，好気的解糖を代 償的に促進する傾向が㒛められた。この中には KCN の ように阻害籄所がチトクローム系に限局されており，理 論的にも，宋た実際代第 10 図のごとく，嫌気的条件下

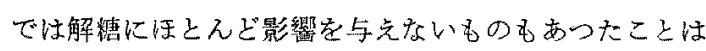
注目される。このことは罵精子内部に呼吸と解糖とを調 節寸る系があり，精子の㭔吸系が阻害刘添加汇上り抑制 された結果，調節系が働いて間接的に解糖を促進したと 解され，興味深い。しかしながら，以上の上うな呼吸阻 害に伴亏解楉の代傥的促進にも拘らず，精子の運動性に 対しては一見活とんど役立つていないような結果が党ら れた. この点 LARDY and PHILLIPS ${ }^{91}$ 活牛精子において, $10^{-3} \mathrm{M}$ 浱度の KCN を添加し呼吸をほとえご完全に抑 制してむ，同時にブドウ䌅を添加すれば，運動阻害は大 いに軽減され，また賦活試験でるほとえど運動阻害を認 めなかつた上報告し，石渡》注脚子に打いて，ブドウ 糖添加が $10^{-3} \mathrm{M}$ 浱度の KCN による運動阻害を同様に 軽減したと報告しているが，熖精子との違いを思わせ る.しかしながら，著者らの成緽においてる仔細に検討 すれば，第 10 図のごとく $10^{-2} \sim 10^{-4} \mathrm{M} \mathrm{KCN}$ の添加の 際にブドウ䌅添加による運動性維持の効果がわずかに認 められ，主大第6 図においても，フルオ口酷酸の阻害を うけて活力がほとえど消失する濃度が，無基質区では 
$10^{-8} \mathrm{M}$ であつたのに比ベ,ブドウ糖添加区では一段と 澱い10-2 M であつたことにる，解䌅の活力維持効果を 認めることができる。一力塖気的条件下では，第 3 図の

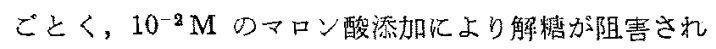
るの上併行して精子活力が阻害されており，第 11

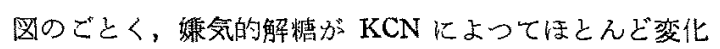
を受けない場合以は，精子の活力名あり抑制を受好 ず， $10^{-3} \mathrm{M}$ においてさえも僅か $20 \%$ 程度が阻害され ただけで活発な運動を続けることが認められたことは、 少く之㧞気的条件下においては，解糖が精子の運動の 主要なエネルギー源となつているととを物語つている. なお上述の呼吸阻害に伴つて代償的に解糖が最む促進さ れたフルオロ酶酸，シフン化カリ，ヒドロオキシルフミ ンの各 $10^{-8} \mathrm{M}$ 添加区においてさ克， $Z_{\mathrm{L}}^{\mathrm{O}_{3}}$ 值 (生成新酸 量 $\mu \mathrm{g} / 10^{8}$ 精子/時間) 法 $25 \sim 46$, 平均 34.7 (実測値, 8 例)で西り，一方参考のた奶に，解糖が精子の運動の 主要なエネルギー源となつていると思われる媳気的条件 下に就年 $Z_{\mathrm{L}}^{\mathrm{N}_{2}}$ 值 21 99, 平均 65.8 (18例) と比較 すれば，前者の方がはるか低く，往つて精子の活力堂 維持するに足るだけのエネルギー必要量に達しなかつた ものとも考文ら机る。

なおてと酸性第 $4 ， 5$ 图のごとく，好気的条件下で代 償的江解糖を促進ずる゙かりでなく，程度の差はあるが

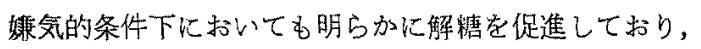

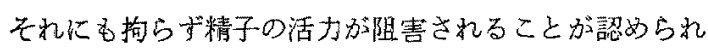
た. フ上酸の精子に対する運動阻害については, 石渡ら が，豚精子は姫铰的条件下において焦性ブドウ酸の不同 変化 (dismutation) 范行なうが，この焦性ブド酸の 代謝が精子の運動性と密接な関連性をもつていること,

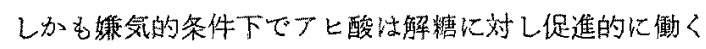

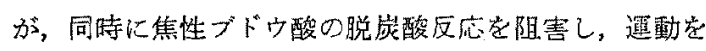
阻害すると報告している，著者らの結果は，実験条件の 差は西るにせ上，明らかに孷酸がス発生は促進されてむ り，焦性ブドウ酸の不同变化が抑制されているとは認め られない，促つてこの場合のブ酸は，解糖や焦性ブド ウ酸の不同変化以外で，しか子精子の運動と関連をむつ ている系を阻害しているものと考えられ，注目される。

以上呼吸阻害削老添加して，鷄精子の呼吸，解糖，運

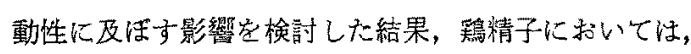
呼吸の消長は精子一活力と密接代関逜しており，好気的 条件下の主なるエネルギー源となつていると考えられ

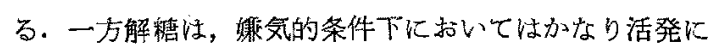
行われ，精子の運動の重要なエネルギー源であると思わ 蚂るが，好気的条件下において性，他の家畜精子に比べ て著しく小さく，かつ㭔吸が抑制された場合にのみ代償
的に增大するが，活力を回復するすでには到らず，運動 性の維持に対しては二楸的のるのであると思われる。

\section{要 約}

鵎精子の呼吸，解糖と運動性との相互関係学追究する

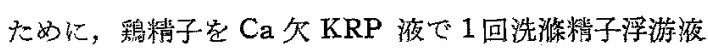

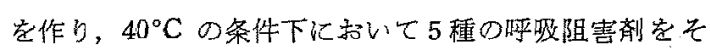
れぞれ添加した際の舟吸，解糖並に運動性に反ぼす影隦 について検討行つた結果，つきの知見它た。

1）マロン酸江内因性呼吸と運動性沈刘して注阻害を 示さないが，プドウ糖を基質にすれば，僅かに阻害があ らわれる。 またコハク酸の同時添加による呼吸量の増大 は，マロン酸添加により強く阻害される。

2）丁ヒ酸，シフン化カリは $10^{-3} \mathrm{M}$ の浱度で，ヒド ロオキシルフミンは $10^{-2} \mathrm{M}$ の浱度で，呼吸䅂よび運動 性を併行的に強く阻害した。ブドウ糖を源加すれば，呼 吸の抑制に伴い代償的に好気的乳酸生成を著しく増す が，運動性比対寺る阻害の軽減は，KCNで僅か儿認め られたにすぎなかた。

3）フルオ口酶酸以内因性呼吸に対しては $10^{-8} \mathrm{M}$ か らブドタ糖港加の際の㴍吸に対しては $10^{-4} \mathrm{M}$ より阻 害を示した。これに伴つて解糖は代償的に促進された

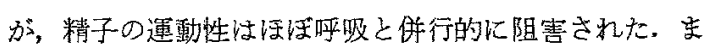
た酶酸ソーダやクェン酸ソーダとフルオ口酢酸との間に 競合的阻害関係が認められた。

4) 以上の結果法，鷄精子の呼吸が TCA サイクルに よつて和り，乙かも好気的条件下では，呼吸解糖より も鵎精子の運勤性に対し，より密接に関連吉ることを示 するのと思われる。

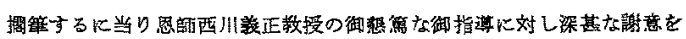

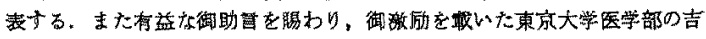

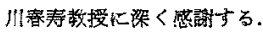

\section{文献}

1) Barker, J.B. and W. H. Summerson (1941) J. Biol. Chem., $138: 535$.

2) HowE, G.R. and R.J. FLIPSE (1959) J. Dairy Sci., $42: 1325$.

3）石渡和男 - 古川美採・高橋泰常（1956）生化 学, 28: 209.

4) - (1956) 同誌, $28: 213$.

5) (1956) 同誌, $28: 437$.
6) $(1957) \quad$ 同誌, $29: 188$.

7) — (1957) 同誌, $29: 250$.

8) LaRdy, H.A. and P.H. Phillips (1941): J. 


\section{鷄精子の代謝之呼吸阻塞剂}

Biol. Chem., $138: 195$.

9) $\longrightarrow$ and (1943) ibid., 148 :

333.

10) $\longrightarrow$ and $(1943)$ ibid., 149 :

177.

11) LiebecQ, C. and R.A. Peters (1949) Biochem. et Biophy. Acta, 3:215.

12) MacLeod, J. (1951) J. Gen. Physiol., 34 : 705.

13) (1953) Testis and Ovary : 123. C.C. Thomas Pub.

14) Mann, T. and C. Lutwak-ManN (1948)
Biochem. J., $43: 266$.

15) Massart, L. (1950) The Enzyme. I : 325. (Ed. Sumner, J.B. and K. MYrB̈̈CK)

16) Morris, D.L. (1948) Science, $107: 1254$.

17) ニーランス゚・スタンプ (中村道䘖訳) (1955) 醏菜化学概論: 380 , 影倉慧店.

18) Quastel, J.H. and W.R. Wooldridge (1928) Biochem. J., $22: 689$.

19) Tosic, J. and A. WALton (1950) Biochem. J., $47: 199$.

20)吉田董雄・㭓田博司 (1961) 京大農蓄創 25 誌: 105.

\section{Résumé}

\section{Biochemical Studies on Fowl Semen \\ II. Effects of some respiratory inhibitors on metabolism of fowl spermatozoa}

\section{Shigeo Yoshida and Hiroshi Masuda \\ (College of Agriculture, Kyoto University)}

In order to study the interrelation between metabolism and motility, investigations were made, at $40^{\circ} \mathrm{C}$, on the effects of five respiratory inhibitors on respiration, glycolysis and motility of fowl spermatozoa which were once washed and suspended in $\mathrm{Ca}$ free KRP. The results are as follows:

1. Malonate showed appreciable inhibition neither on endogenous respiration nor on motility but it showed a slight inhibition in glucose containing suspension. The addition of succinate brought about an increase in the rate of oxygen consumption but this was made invalid by the addition of malonate.

2. Respiration was greatly inhibited by arsenite and cyanide at the concentration of $10^{-3} \mathrm{M}$ and by hydroxylamine at $10^{-2} \mathrm{M}$. The inhibition of respiration caused that of sperm motility. In the presence of glucose, the accumulation of lactic acid was stimulated compensatorily with the inhibition of respiration but the inhibition of motility was relieved only in the case of cyanide.

3. Fluoroacetate inhibited respiration at the concentration of $10^{-8} \mathrm{M}$ in the absence of glucose and at $10^{-4} \mathrm{M}$ in the presence of glucose. Though glycolysis was increased compensatorily, the inhibition of sperm motility was quite parallel to that of respiration. The competitive inhibition between fluoroacetate and sodium acetate or sodium citrate was observed.

4. The above results suggest that the respiration of fowl spermatosoa is carried out through TCA cycle and that it is more closely related to their motility than to the rate of glycolysis. 